\title{
Research on Apple Inc's Current Developing Conditions
}

\author{
Qian Zhang \\ Culverhouse College of Commerce, University of Alabama, Tuscaloosa, USA \\ Email: Qzhang30@crim son.ua.edu
}

How to cite this paper: Zhang, Q. (2018) Research on Apple Inc's Current Developing Conditions. Open Journal of Business and Management, 6, 39-46.

https://doi.org/10.4236/ojbm.2018.61003

Received: October 16, 2017

Accepted: December 23, 2017

Published: December 26, 2017

Copyright $\odot 2018$ by author and Scientific Research Publishing Inc. This work is licensed under the Creative Commons Attribution International License (CC BY 4.0).

http://creativecommons.org/licenses/by/4.0/

\begin{abstract}
This paper has discussed current developing situations of Apple Inc, and based on its choices and sale conditions, this paper analyzes its advantages, disadvantages and outside effects such as financial problems with PESTEL and other popular analyzing methods. After these analysis, the paper gets a conclusion that although the high-quality products and good brand awareness of Apple Inc allow this company to attract an lot of potential customers and strengthen their loyalties, it is also very important to capture the market shares from other strong competitors such as Dell, Samsung, and Lenovo by investing more money into the emerging markets than other rivals, keeping innovation and lowering pricings.
\end{abstract}

\section{Keywords}

Apple Inc, technology Industry, Market Expanding

\section{Introduction}

Apple Inc belongs to the technology industry, which is the most valuable and growing industry in global market. The technology industry has two major sectors: hardware and software. On one hand, Dell, Lenovo, Samsung, Intel, Sony, and Xiaomi are the representatives of the hardware [1]. Their business includes the personal computer, mobile phone, tablet, music player, and other electronic devices. On the other hand, IBM, Microsoft, and Android are participating in the software sector. Besides, some other companies like Apple Inc and Google are playing the important role in the both sectors. In the technology industry, every large successful company has some similar strategies in quality, price, innovation, globalization, and consumer spending area [2]. By the development of the science, an increasing number of companies invest in the technology industry. And the competition is becoming fiercer between the companies in the ma- 
turity markets and emerging markets. Most companies launch their new products with the most advanced technology or concepts in each year. The leader in the technology industry will create the new standard or rules based on their products, and the followers always produce the products around popular standards [3]. Many median or small size companies are providing the products with low price and high performance to take the market share from the large companies. By saturating in the western market, those technology companies are aiming to expand in emerging markets like China. And those companies outsourced the assembling process to some Asian countries to lower the cost and earn more profit [4].

Apple Inc was created by Steve Jobs and Steve Wozniak in 1976 [5]. At the beginning, Apple Inc only produced easy-to-use computer to the PC market. Due to the special designing and revolutionary concepts, Apple Inc became the industry leader since 1980. At the same year, Apple Inc launched a successful IPO. Nowadays, Apple Inc is the most valuable company in the history of the world [6]. Apple Inc created a lot of revolutionary products like Macintosh, iPod, iPhone, iPad, and Apple watch. This company also brought some great applications and system, like iOS and Apple Pay to consumers as well. In the future, Apple Inc is going to challenge the unfamiliar industries such as car and cable. After the death of founder Jobs, Apple Inc is trying to creating the new legendary stories under the lead of new CEO Tim Cook.

\section{Current Developing Strategies}

Apple Inc's current strategy is designed to improve two key areas: products and marketing. It aims to strengthen the ability of competition in the technology market.

Apple Inc's product strategy focuses on three aspects. Firstly, introducing more innovations and expand its product lines. Apple Inc launches a new generation of product every year. By improving the performance and using new technologies on the products to defeat the rivals in the mobile phone, tablets, and computer market. Secondly, Apple Inc creates more new products routinely to catch the market shares. The Apple Watch and Apple Pay become the star products and concepts in the whole market. Consumers are willing to buy the service and advanced technologies to improve their life. In the future, Apple Inc is going to compete in the traditional car and new energy car industry. Thus, Apple Inc paid a lot attention on the customer experience to expand the unknown area in the technology industry.

The Marketing strategy for Apple Inc is to build a global brand through all the markets [7]. It tried its best to keep expanding the customer base, attracting new customers, and strengthening the connection with loyal customers by launching new products and expanding on the emerging market. According to its financial data in 2015, sales were particularly robust in China, the world's largest smartphone market [8]. Apple Inc knows the importance of the emerging market like China in the world. The great number of potential consumers means huge prof- 
its to the company. Thus, Apple Inc produced iPhone 5C to move down-market. The lower price and similar functions are good ways to increase the consumption in those kinds of markets.

\section{Analysis of Apple Inc's Condition}

\subsection{PESTEL Analysis}

A PESTEL analysis is based on the macro environment of an industry and analysis how it could affect the whole technology industry. PESTEL focuses on six aspects: political factors, economic conditions, socio-cultural forces, technological factors, environmental forces, and legal factors.

- Political Factors-Weak

The case did not describe political factors that influenced the technology industry, so the political factors are weak to technology companies, electronic devices manufacturers, and consumers. However, Apple Inc outsources its production and assembling to global sourcing, which was subject to strict producing control and must meet the requirements from foreign governments. Besides, the other foreign brands such as Xiaomi and Samsung may get the support, protection, and special treatments from their domestic countries, which could cause fiercer competition in the current market.

- Economic Conditions-Strong

The economic conditions have the strong effects on technology industry companies. In the aftermath of the recessions and economic slowdowns since 2008, the emerging country like China has become the world's largest smartphone market. Besides, the labor cost and materials cost are both affected by the general economic conditions. Thus the price of electronic products has to change the pricing strategy in the different periods.

- Socio-cultural Forces-Moderate

Socio-cultural forces have the moderate effects. Consumers want to spend less money but have the similar or even better quality of products in consumption. Thus, an increasing number of brands would like provide the products with high performances and low prices to reach the customers' requirements.

- Technological factors-Strong

Technological factors were also strongly affected the technology industry. The advantages in technology are the core strengthens to a technology company in the market. Technological factors not only affect the hardware, but also decide the development of software and peripherals in the market. On the other hand, the innovation promotes the technology for the market and brings the most profits for the leader.

\subsection{Five Forces Analysis}

Apple Inc is necessary to use Five Forces to access the current situation, market shares, and profitability in the current market and technology industry. It is helpful to evaluate the competition from new entrants, rivals, substitute, and 
bargaining power from customer and supplier.

- Competition from new entrants-Weak

The force of competition from new entrants is weak to Apple Inc, because Apple Inc already built a strong brand awareness in worldwide and attracted a huge number of loyal customers in the past 40 years since 1976. Besides, Dell, Lenovo, HP, Samsung already take the rest of market share. Those companies not only have the long history, but also have very deep understanding of customers' needs and experienced skills as well. Therefore, the new entrants are not easily to challenge Apple Inc at price prime market in the short time. However, Apple Inc should not ignore some new entrants like Xiaomi with low cost in the market. In the long term, the new entrants are able to take the market share from Apple Inc in the emerging market such as China.

- Competition from substitute-Moderate

The force of competition from substitutes is moderate to Apple Inc. Apple Inc has a group of loyal customers due to its quality and value. However, other technology companies are able to provide the similar products to customers as well, such as phones, PC, tablets, and watch. So Apple Inc provides a less uniqueness from its rivals like Sony, Dell, HP, Samsung, and Google. For example, PS3 allowed customers to watch videos, surf the websites, and play the games. And Customers are willing to purchase the similar designing and quality goods at a relatively lower price in the technology market. Therefore, Apple Inc has to introduce truly innovation new products to take market shares from substitutes.

- Competition from customer bargaining power-Strong

The force of competition from customer bargaining power is strong to Apple Inc, because Apple Inc is one of the large technology company in the world. Customers have many options in the electronic products from various brands. In the software area, customers can also purchase the application from Microsoft or Google.

- Competition from supplier bargaining power-Weak

The force of competition from supplier bargaining is week to Apple Inc, because Apple Inc doesn't have various options in choosing materials like battery, microprocessors, and protocols from many suppliers in the market. Qualcomm provides the most important protocols for wireless service, like CDMA(3G) and LTE(4G). Apple Inc has to co-work with Qualcomm to save the cost instead of studying this technology by itself. On the other hand, the Intel and ARM produces the CPU for computers. There are not many companies have the ability to do produce the most important part for phones and computers in the market.

- Competition from rival sellers-Strong

The force if competition from rival sellers is strong to Apple Inc in the market. Dell, HP, Lenovo, and Google strongly challenge Apple Inc in personal computer area. Xiaomi, Samsung, and Lenovo compete with iPhone in mobile phone area. Thirdly, Android and Microsoft share the market share with IOS system. The rivals also produce the high quality products and service to consumers. However, innovation is the most valuable strengthens than its rivals. 
Thus Apple Inc still has the higher market share and sustainable growth in profits. As the leader in technology industry, Apple Inc needs to find the more opportunities and creative ideas to keep the advantages in those areas.

\subsection{Financial Analysis}

\subsubsection{Solvency Analysis}

As can be seen from the above Table 1, Apple Inc's current ratio and quick ratio showed a downward trend, indicating that the company's solvency is weak. At the same time, the company has a high financial risk.

\subsubsection{Operating Capacity Analysis}

As can be seen from the Table 2, Apple Inc's total asset turnover rate decreased year by year, indicating that Apple Inc's asset utilization has been reduced, the company's operating capacity is weakening. Income continues to increase, indicating that the Apple Inc market continues to expand.

\subsubsection{Profitability Analysis}

According to the VRINE analysis, we can easily figure out the advantage of Apple IncInc with the data in Table 3 and Table 4. in its Brand. Customers believe in the brand and have willing to buy the products from Apple Inc. Besides, the technology and innovation are the most important for Apple Inc to maintain the advantages in the market. However, we cannot ignore the price of all products from Apple Inc. On the one hand, the high price will bring more profits to Apple Inc. On the other hand, Apple Inc will lose the low-income consumers' market. That is reason why Xiaomi is becoming the strongest competitor in emerging market and developing countries.

\subsection{Market Share Analysis}

From the Table 5 can be seen, Android system market share increased year by year and there are more than iOS system trends. This shows that the Android system will become Apple Inc's strong competitors.

\section{Conclusion and Suggestions}

\subsection{Conclusion}

The high-quality products and good brand awareness of Apple Inc allow this company to attract an increasing number of potential customers and strengthen their loyalties. It is very important for a company to capture the market shares from other strong competitors such as Dell, Samsung, and Lenovo. In addition, Apple Inc can invest more money into the emerging markets to take market share than other rivals by advertising, and lower the prices. Apple Inc is very good at cutting the cost and learning from the competitor, which should be developed. Besides, introducing more innovations and great designs for consumers are also necessary. Finally, Apple Inc should pay more attention to the unfamiliar but growing new industries such as the new energy automobile. 
Table 1. Financial conditions.

\begin{tabular}{ccccc}
\hline Item & 2011 & 2012 & 2013 & 2014 \\
\hline Current assets & 44,988 & 57,653 & 73,286 & 68,531 \\
Current liabilities & 27,970 & 38,542 & 43,658 & 63,448 \\
Inventory & 776 & 791 & 1764 & 2111 \\
Flow ratio & 1.60 & 1.50 & 1.68 & 1.08 \\
Quick ratio & 1.58 & 1.48 & 1.64 & 1.05 \\
\hline
\end{tabular}

Data from http://investor.apple.com/financials.cfm. Formula: Current ratio = current assets/current liabilities; Quick ratio $=($ current assets - inventory $) /$ current liabilities.

Table 2. Asset turnover rate.

\begin{tabular}{ccccc}
\hline Item & 2011 & 2012 & 2013 & 2014 \\
\hline Operating income & 108,249 & 156,508 & 170,910 & 182,795 \\
Average total assets & 116,371 & 176,064 & 207,000 & 231,839 \\
Total asset turnover (number of times) & 0.93 & 0.89 & 0.83 & 0.79 \\
Total assets turnover days & 392 & 410 & 440 & 462 \\
\hline
\end{tabular}

Data from http://investor.apple.com/financials.cfm. Formula: Total assets turnover = operating income/ average total assets; Total asset turnover days $=365 /$ total asset turnover.

Table 3. Revenue changes.

\begin{tabular}{ccccccccc}
\hline & 2002 & 2006 & CAGR & \%Change & 2010 & 2014 & CAGR & \%Change \\
\hline Total Revenue & 5742 & 19,315 & 35.43 & 70.27 & 65,225 & 182,795 & 29.39 & 64.32 \\
$\begin{array}{c}\text { Most revenue } \\
\text { from }\end{array}$ & MAC & iPod & & & iPhone & iPhone & & \\
COS & 4534 & 7676 & & & 25,179 & 10,199 & & \\
Gross Profit & 1603 & 5598 & 36.7 & 71.36 & 25,684 & 70,537 & 28.73 & 63.59 \\
$\begin{array}{c}\text { Gross profit } \\
\text { Margin (\%) }\end{array}$ & 27.9 & 28.9 & 0.94 & 3.6 & 39.4 & 38.6 & -0.51 & -2.05 \\
Operating profi & 48 & 2.5 & 167.4 & 98.1 & 18,385 & 52,503 & 30 & 64.98 \\
$\begin{array}{c}\text { Operating Profit } \\
\text { Margin \% }\end{array}$ & 0.84 & 12.7 & 97.19 & 93.73 & 28.19 & 28.72 & 0.47 & 1.85 \\
$\begin{array}{c}\text { Net Income } \\
\text { ROA }\end{array}$ & 65 & 1989 & 135.2 & 96.73 & 14013 & 39,510 & 29.85 & 64.53 \\
$\quad 1.03$ & 11.56 & 83.03 & 91.1 & 18.64 & 17.04 & -2.22 & -9.39 \\
$\quad$ ROE & 1.59 & 19.92 & 88.14 & 92.02 & 29.32 & 35.42 & 4.84 & 17.22 \\
$\begin{array}{c}\text { Debt to Asset } \\
\text { Ratio }\end{array}$ & 0.35 & 0.42 & 4.66 & 16.65 & 0.37 & 0.52 & 9.25 & 28.08 \\
\hline
\end{tabular}

Data from http://investor.apple.com/financials.cfm.

\subsection{Suggestions}

Apple Inc has some main rivals, like Lenovo, Xiaomi, Samsung, and Google. Xiaomi is becoming the strongest competitor to Apple Inc in China market. Xiaomi provides lower cost and lower price mobile phones to the down-market, 
Table 4. Resources condition.

\begin{tabular}{|c|c|c|c|c|c|}
\hline & Valuable & Rare & Inimitable & Nonsubstitutable & Exploitable \\
\hline Brand & $x$ & & & $x$ & $x$ \\
\hline Technology & $x$ & $x$ & & & $x$ \\
\hline Innovation & $x$ & $x$ & & & $x$ \\
\hline Quality & $x$ & & & & $x$ \\
\hline Growth & $x$ & & & & $x$ \\
\hline Price & $x$ & & & & \\
\hline
\end{tabular}

Data from http://investor.apple.com/financials.cfm.

Table 5. Market share condition.

\begin{tabular}{ccccc}
\hline Os & 2010 & 2011 & 2012 & 2014 \\
\hline ios & 14,766 & 47,964 & 68,670 & 138,497 \\
Market Share (\%) & 83.9 & 68.7 & 63.5 & 47.1 \\
Android & 2502 & 13,898 & 26,382 & 113,457 \\
Market Share (\%) & 14.2 & 19.9 & 24.4 & 38.6 \\
MeeGo & 107 & 788 & 1271 & 3057 \\
Market Share (\%) & 0.6 & 1.1 & 1.2 & 1.0 \\
Webos & 0 & 2796 & 4245 & 8886 \\
Market Share (\%) & 0 & 4.0 & 3.9 & 3.0 \\
QNX & 0 & 3901 & 7134 & 29,496 \\
Market Share (\%) & 0 & 5.6 & 6.6 & 10.0 \\
Other operating systems & 234 & 432 & 510 & 700 \\
Market Share (\%) & 1.3 & 0.6 & 0.5 & 0.2 \\
Total Market & 17610 & 69,780 & 108,211 & 294,093 \\
\hline
\end{tabular}

Data from http://investor.apple.com/financials.cfm.

where most of consumers are not able to afford the Apple Inc's products. As a result of that, Xiaomi's products become a perfect alternative choice for the lower income consumers. Google created a new PC named chromebook recently. Chrombook provides the necessary functions and good customer services to consumers at a very low price. That is the reason why Google, Dell, and Samsung can quickly capture the emerging market with their PCs and tablets. The correct pricing strategy is helpful to a company to increase its competitive abilities. The following strategies may bring good performances for the company:

- Updating the new technology for products

- Strengthening the compatibility with other brands

- Building multiple strong distribution channels

- Reducing cost by Global sourcing

- Focusing on the emerging markets and down-market 
- Focusing on core designs and launching new products routinely

- Lowering the price and providing high performance products

\section{References}

[1] Barrows, C.W., Hoines, J., Vamstad, M.S., Murphy-Mariscal, M., Lalumiere, K. and Heintz, J. (2016) Using Citizen Scientists to Assess Climate Change Shifts in Desert Reptile Communities. Biological Conservation, 195, 82-88. https://doi.org/10.1016/j.biocon.2015.12.027

[2] Beneke, J. and Trappler, E. (2015) The Might of the Brand: A Comparative Analysis of Brand Prevalence in an Emerging Market Setting. British Food Journal, 117, 485-505. https://doi.org/10.1108/BFJ-06-2014-0192

[3] Corsi, P., Morin, D., Corsi, P. and Morin, D. (2015) 7. Apple Inc, the Learning Company. Sequencing Apple Inc's DNA. John Wiley \& Sons, Inc. https://doi.org/10.1002/9781119261575

[4] Ren, J.J. (2015) Study on the Mobile os Market Based on Population Competition Mode-With the Apple Inc Company as an Example. Journal of Lanzhou Petrochemical College of Vocational Technology.

[5] Stephan, K. (2017) Is Apple Losing Its Shine?: Concerns over Worker Safety in Chinese Consumer Electronics Factories. IEEE Consumer Electronics Magazine, 6, 101-102. https://doi.org/10.1109/MCE.2016.2640679

[6] Theodore, S. (2005) Brand It like Apple. Beverage Industry.

[7] Weiss, M.B.H. (1991) Compatibility Standards and Product Development Strategy: A Review of Data Modem Developments. Computer Standards \& Interfaces, 12, 109-122. https://doi.org/10.1016/0920-5489(91)90060-D

[8] Zhang, X.Y., Zhu, H.X. and Zhang, H.X. (2005) Present Situation and Developing thought of Apple Industry in Shaanxi. Journal of Northwest University. 